\title{
THE DYNAMICS OF THE PRIVATIZATION AND THE STATE OF PROPERTY RELATIONS IN 2012

\author{
A.Radygin, G.Malginov
}

The results of 2012 clearly pointed to the fact that the classical set of problems specific to the Russian privatization - justification of the fair price for assets to be privatized, real motivation of the participants, determination of the criteria of selection of the buyer, ensuring of transparency and claims of regulating authorities - remain topical. Also, there has been no analysis of the potential effects of the privatization with its expediency, alternative costs, possible risks and effects on individual markets, industries, regions and the country's economy as a whole taken into account.

Implementation of the three-year privatization program - which is the first one in the contemporary history - has entered its final stage. As the forecast plan of privatization for the 2011-2013 period adopted by the Government of the Russian Federation as early as November 2010 covered a three-year period at the time of approval, the above document was later only amended and supplemented; it is to be noted that in 2012 the rate at which amendments were made was much higher than before. From the time of approval - by Resolution No. 2102-r of November 27, 2010 of the Government of the Russian Federation - of the forecast plan (program) of privatization of the federal property and the main guidelines of privatization of the federal property in the 2011-2013 period, thirty-six respective statutory acts were passed with 24 of them approved in 2012, against 11 statutory acts in 2011 .

As a result, the most important difference from the original version of the program consisted in a serious radicalization of privatization plans as regards large companies where the state permitted a reduction of its share in the capital, as well as expansion of the list of assets to be privatized.

It is to be reminded that the initial privatization program included ten companies, while in 2011 the format of reduction of the share of the state in the following open joint-stock companies - the Federal Hydro-Generating Company (RusGidro) and the United Grain Company (Obiedinennaya Zernovaya Kompania (OZK)) - with preservation of the controlling interest of $50 \%$ plus one share was specified.

Generally, the process of privatization of shares of large joint-stock companies in the 2012-2013 period was specified by Resolution No. 1035-r of June 20, 2012 of the Government of the Russian Federation.

Subject to privatization were such open joint-stock companies as OZK (the state ends up its participation in the charter capital), Sovremenny Kommerchesky Flot (50\% minus one share), Rosagrolizing (49.9\% minus one share), VTB Bank (25.5\% minus one share), Rossiiskie Zheleznye Dorogi ( $25 \%$ minus one share), Sberbank of Russia (7.58\% minus one share) with the prospect of termination of the state's participation in their capital till 2016 (except for OAO Sberbank of Russia and OAO RZhD). A similar measure was declared in respect of other open joint-stock companies, such as Zarubezhneft, RusHydro, INTER RAO UES, the Sheremetievo International Airport, Aeroflot, Rosselkhozbank and ALROSA. In a number of companies - Transneft, FSK UES and Uralvagonzavod - the share of the state is to be reduced to $75 \%$ plus one share, while in the Objedinennye Sudostrointelnaya and Aviastroitelnaya Korporatsii (United Shipbuilding and Plane-Making Corporations) the share of the state is to be cut to $50 \%$ plus one share.

In addition to the above, it is expected to reduce the interest of the state in the capital of OAO ROSNANO to $90 \%$ by issuing and placement of additional shares, while starting from 2013 assignment of shares of OAO Rosneft with termination of the state participation in the capital of that company by 2016 and shares of OAO Rosneftegas (with OAO Rosneftegas permitted to act as an investor in privatization of companies of the fuel and energy sector prior to the beginning of 2015 provided that a program of funding of such deals is available; the above program has to provide for utilization of dividends from equities of the companies which are owned by the above joint-stock company) is planned. 
It is to be noted that such a radical change in the privatization policy towards giving up by the state of control over a dozen large companies of nationwide importance was not accompanied by any compensating measures, except for a possibility to use a special right to participation by the Russian Federation in management of joint-stock companies ("a golden share") in respect of less than a half of those companies (Obiedinennaya Zernovaya Kompania (United Grain Company), Zarubezhneft, RusHydro, Aeroflot and ALROSA).

In 2012, the largest privatization deal was a sale of a $7.58 \%$ package of shares - owned by the Central Bank of the Russian Federation - of OAO Sberbank of Russia for Rb 159.3bn. The specifics of the deal related to a special public and legal status of the seller which is different from the classical role of the authorities which are in charge of property management justified the need of approval of special amendments to the Federal Law on the Budget in 2012 and the 2013-2014 Planned Period in order to ensure proper replenishment of the budget from that source. Early in December 2012, it was established that a portion of funds received by the Central Bank of the Russian Federation from the sale of shares of OAO Sberbank of Russia in the amount which is determined as the difference between the amount of proceeds from the sale of the above shares and their balance-sheet value, less the amount of costs related to the sale of the above shares is subject to payment to the federal budget with respective reduction of the portion of profit - liable to payment to the federal budget - received by the Central Bank of the Russian Federation on the basis of the results of 2012 .

In the past year as a year before, the specific aspect of the privatization was a sale of federal packages of shares through sellers (mainly investment banks) which were designated by the government; almost all the major deal were carried out through them:

- AO SG-Trabs (sale of $100 \%$ of shares for Rb 22.77bn; manager - OOO Renessans Broker; buyer - OAO AFK Sistema);

- Vanino Maritime Commercial Port (the Khabarovsk Territory) (sale of $73.33 \%$ of common shares or $55 \%$ of the charter capital for Rb 15.5bn; manager - VTB Capital; buyer - OOO Mechel-Trans);

- OAO Apatit (sale of $26.67 \%$ of shares or nearly $20 \%$ of the charter capital for Rb $11.1 \mathrm{bn}$ ); manager - ZAO BNP PARIBA Bank; buyer - OAO FosAgro);

- Murmansk Maritime Commercial Port (sale of 25.5\% of shares for Rb 2.2bn; manager - OOO,

- Raiffeisen Investment, buyers - OAO SUEK and Alfa Capital Holdings (Cyprus) Limited).

Troika Dialog, a company controlled by OAO Sberbank of Russia acted as a manager of additional issuing of a share (50\% minus one share) in OAO OZK for Rb 5,951bn.

The principal difference of the 2012 privatization process from that of the previous year was a negative background which emerged for the first time in the past few years. It was caused, in principle, by the developments which took place last autumn around OAO Oboronservis, however, the situation around the deals related to the sale of assets which were regarded attractive for investment contributed largely to aggravation of that background.

It concerns disputing in the Federal Antimonopoly Service of the Russian Federation of the results of the private offering of equities of OAO OZK on the part of the Bazovy Element, a business group whose interests were represented by the Kuban Agro-Holding and a court ruling as regards a claim of ZAO RN-Trans, a subsidiary of OAO Rosneft to OOO Renesans Broker, manager of the tender on sale of $100 \%$ of equities of OAO SG-Trans to ban further alienation of those equities from the federal property. Eventually, both the claims of the entities which expressed discontent with the results of privatization deals were not satisfied. In particular, in case of OAO SG-Trans the court lifted the injunctive measures, while OAO Rosneft waived its claims and withdrew an action. According to the unofficial information, the above took place after the new owner of OAO SG-Trans - AFK Sistema - guaranteed to OAO Rosneft a long-term contract on transportation of liquefied hydrocarbon gas.

In connection with the policy aimed at ensuring higher transparency and de-offshorization of the economy which policy was declared at the country's highest political level, a resale of the stateowned package of shares of OAO Vanino Maritime Commercial Port to OAO Mechel - which deal became known in January 2013 after only a month and a half from the date of purchasing of that asset from the state - triggered a more dramatic public reaction. 
On the one side, the management of OAO Mechel justified the above deal by the need to find a base for selling the coal produced at the Elginsk coal deposit in Yakutia. The state-owned package of shares with the initial price of $\mathrm{Rb}$ 1.5bn was sold for $\mathrm{Rb}$ 15.5bn though OAO Mechel experienced the highest debt load among all the Russian mining companies. On the other side, it was stressed in the statement of $\mathrm{OOO}$ Mechel-Trans, a subsidiary of the holding that new "investors had no interest in transshipment of cargo through the port of Vanino". Neither the composition of the new owners of the port, nor the amount of the resale deal were specified. Soon after that, South Korean companies were named among new owners, however, later the information emerged that three Cyprian-based companies became the owners. However, judging by statements made by Russian officials that news is not regarded as the one which has caused much concern.

In mid-December, in consideration by the Collegium of the Auditing Chamber (AC) of the results of verification of development and implementation of privatization plans for the 2011-2014 period it was stated that there was no statutory and procedural documents determining the content of expenditure liabilities required for privatization. Auditors pointed out that the Ministry of Economic Development of the Russian Federation failed to ensure transparency of procedures for approval of decisions on the terms of privatization of some companies.

Despite declarations to make the privatization process more transparent, as of mid-April the authorities did not provide the aggregate data on the course of privatization process in 2012 . Nor was that data mentioned in the statement of the head of the Ministry of Economic Development of the Russian Federation at the meeting of the government on February 7, 2013, except for the fact that in the past three years only 284 unitary enterprises were included in the privatization program in order to be transformed into joint-stock companies; it is to be noted that $70 \%$ of the above enterprises was already transformed into joint-stock companies.

In 2012, within the frameworks of privatization 273 packages of equities of joint-stock companies $^{1}$ were sold which figure is almost a quarter lower than the value of the year 2011 (359 jointstock companies; in 2010 - 134 joint-stock companies). So, though the index in question exceeds the results of the 2008-2010 crisis period, however, it is below the 2006-2007 level.

As regards the public sector of the Russian economy, the most important developments in 2012 were the great efforts taken to upgrade transparency of state-owned companies' activities, while as regards the structural policy it was a decision on reformatting of the state presence in the electric power industry.

It is to be reminded after completion of a lengthy process of restructuring with liquidation of RAO UES of Russia in summer 2008 the state became the owner of controlling interests in two infrastructure companies: the Federal Network Company of the Unified Energy System (OAO FSK UES) and the Holding of Inter-Regional Network Companies (OAO Holding MRSK).

Decisions approved in the second half of November 2012 envisaged renaming of the latter into OAO Rossiiskie Seti (the Russian Networks) (the share of the state amounted to 54.52\%) with contribution of almost the entire package of shares of OAO FSK UES (79.5\%) to the charter capital of that company by way of payment for additional shares to be placed by OAO Rossiiskie Seti due to an increase in the charter capital with preservation of direct participation of the state in the capital of OAO FSK UES in the amount of no less than one share. Also, as regards OAO Federal Hydro-Generating Company (RusGidro) it is expected to increase the charter capital with determination of the minimum possible share of the state at $60.5 \%$. As a contribution of the state it is planned to use packages of shares of four open joint-stock companies (two minority packages and two blocking packages) and funds in the amount of maximum Rb 50bn at the expense of the 2012 federal budget allocations.

Such a decision is to a certain extent in conflict not only with amendments approved last June to the privatization program for the 2011-2013 period, but also with a lower threshold of the state corporate control - 50\% plus one share - established in respect of OAO RusGidro in 2011. At the same time, contribution of almost the entire federal package of shares of OAO FSK UES to the charter capital of OAO Rossiiskie Seti exceeds greatly the limits of the modest reduction of the

1 RIA RosBisnesKonsulting, 07.02.2013. The data was provided with reference to the information received from the press-service of Rosimuschestvo on January 16, 2013 though it is not available on the Web-site of the above agency. 
share of the state to $75 \%$ plus one share; the above reduction was announced in the existing privatization program as amended.

Apart from the electric power industry, decisions which involve formation of integrated structures concern geodesy (OAO Roskartografia) and the agro-industrial complex (OAO Rosspirtprom and OAO Rossiiskie Ippodromy).

It is envisaged to expand holdings which operate as joint-stock companies (Takticheskoe Raketnoe Vooruzhenie Corporation, Granit-Elektron Concern, Morskoe Podvodnoe Oruzhie - Gidropribor Concern, Tsentr Tekhnologii Sudostroenia i Sudoremonta (Center for Shipbuilding and ShipRepairing Technology), Okeanpribor Concern and F.E. Dzerzhinsky Uralvagonzavod, a research and production corporation), as well as some state corporations (Rostekhnologii and Rosatom).

GK Vneshekonombank is included in the future scheme of indirect state corporate control over OAO Rostelekom. It is expected that the latter will be restructured in the form of a merger with OAO Investitsionnaya Kompania Svyazi (better known as OAO Svyazinvest), excluding the latter from the list of strategic entities on a condition that a joint control of the government and GK Vneshekonombank will be established over more than 50\% of common shares of OAO Rostelekom. Meanwhile, restructuring of the state-owned segment of the telecommunications industry is at the stage of secondary offering of shares of OAO Svyazinvest; under the above offering the state will hand over to the holding the profile assets (including interests in OAO Tsentralny Telegraf, OAO Bashinformsvyaz and other companies). For preservation of its interest in OAO Svyazinvest (25\% plus one share with the remaining capital owned by the state), OAO Rostelekom has to participate with cash funds in the secondary offering.

In March 2013, OAO Rosneft completed the deal on acquisition of TNK-BP which deal was the largest one in the Russian market of takeovers and mergers.

Evaluation of the budget effect of the government's property policy depends largely on the selected range of sources as regards privatization and utilization of state property. According to the data of the Federal Treasury, in 2012 the aggregate volume of revenues of the federal budget from privatization (sale) and utilization of state property rose by $30 \%$ as compared to 2011 (Table 1); it is to be noted that that value (about $\mathrm{Rb} 310 \mathrm{bn}$ ) has become the absolute maximum since the beginning of the 2000 s.

In 2012, the share of non-renewable sources in the structure of revenues from privatization (sale) and utilization of state property as compared to the previous year decreased by $54.6 \%$ (to $26.1 \%$ ) and was equal to the level of 2006 though it exceeded the values of the 2007-2010 period. On the contrary, the unit weight of the revenues from utilization of state property rose from $43.3 \%$ in 2011 to nearly $74 \%$ in 2012 . As regards the absolute value, the above result is the maximum one and exceeded by $120 \%$ the 2011 result, while the revenues from privatization (sale) of property turned out nearly $40 \%$ and 14\% lower than in 2011 and 2003, respectively (the previous maximums).

The situation changes dramatically with taking into account the revenues from the sale of shares of OAO Sberbank of Russia through the Central Bank of the Russian Federation. In that case, the share of non-renewable sources in the structure of the aggregate revenues from the privatization (sale) and utilization of state property will be more than a half (around 51\%), however, it is below the same index of 2011 (56.7\%).

The law on the federal budget in 2013 and the 2014-2015 planned period does not include the information on the specific value of the revenues from privatization neither in the body, nor in the annexes which deal with the sources of financing of the deficit of the federal budget where only an aggregate item on other sources - without any breakdown - is listed among other things. However, it is necessary to point out the subordinate role of the revenues from the privatization in making up the deficit of the federal budget and the possibility of utilization of a portion of the extra oil and gas revenues for substitution of sources of financing by analogy with the maneuver provided for by amendments to the federal budgets of the previous two years.

The forecasts of privatization revenues voiced in the first few months of this year are within a broad range: from $\mathrm{Rb} 60 \mathrm{bn}$ according to the estimate of the Ministry of finance to $\mathrm{Rb}$ 100bn according to the estimate of the Ministry of Economic Development of the Russian Federation (instead of $\mathrm{Rb} 427 \mathrm{bn}$ as was announced in the explanatory note to the draft federal budget in 2013 and the 2014-2015 planned period submitted to the State Duma last autumn). 
THE STRUCTURE OF FEDERAL BUDGET REVENUES OF PROPERTY NATURE FROM DIFFERENT SOURCES IN THE 2000-2012 PERIOD

\begin{tabular}{|c|c|c|c|c|c|c|}
\hline \multirow{2}{*}{ Year } & \multicolumn{2}{|c|}{$\begin{array}{c}\text { Aggregate revenues from } \\
\text { privatization (sale) and } \\
\text { utilization of state property }\end{array}$} & \multicolumn{2}{|c|}{$\begin{array}{c}\text { Revenues from privatization } \\
\text { (non-renewable sources)* }\end{array}$} & \multicolumn{2}{c|}{$\begin{array}{c}\text { Revenues from utilization } \\
\text { of state property } \\
\text { (renewable sources)** }\end{array}$} \\
\cline { 2 - 7 } & $\begin{array}{c}\text { Million Rb } \\
\text { result }\end{array}$ & Million Rb & $\begin{array}{c}\text { \% of the } \\
\text { result }\end{array}$ & Million Rb & $\begin{array}{c}\text { of the } \\
\text { result }\end{array}$ \\
\hline 2000 & 50412.3 & 100.0 & 27167.8 & 53.9 & 23244.5 & 46.1 \\
\hline 2001 & 39549.8 & 100.0 & 10307.9 & 26.1 & 29241.9 & 73.9 \\
\hline 2002 & 46811.3 & 100.0 & 10448.9 & 22.3 & 36362.4 & 77.7 \\
\hline 2003 & 135338.7 & 100.0 & 94077.6 & 69.5 & 41261.1 & 30.5 \\
\hline 2004 & 120798.0 & 100.0 & 70548.1 & 58.4 & 50249.9 & 41.6 \\
\hline 2005 & 97357.4 & 100.0 & 41254.2 & 42.4 & 56103.2 & 57.6 \\
\hline 2006 & 93899.8 & 100.0 & 24726.4 & 26.3 & 69173.4 & 73.7 \\
\hline 2007 & 105761.25 & 100.0 & 25429.4 & 24.0 & 80331.85 & 76.0 \\
\hline 2008 & 88661.7 & 100.0 & 12395.0 & 14.0 & 76266.7 & 86.0 \\
\hline 2009 & 36393.7 & 100.0 & 4544.1 & 12.5 & 31849.6 & 87.5 \\
\hline 2010 & 88406.4 & 100.0 & 18677.6 & 21.1 & 69728.8 & 78.9 \\
\hline 2011 & 240964.1 & 100.0 & 136660.1 & 56.7 & 104304.0 & 43.3 \\
\hline 2012 & 309875.8 & 100.0 & $80911.3 /$ & $26.1 /$ & 228964.5 & $73.9 /$ \\
\hline
\end{tabular}

* includes revenues from sale of shares, land plots and different property which is in federal ownership;

** includes the dividends and income from other forms of participation in the capital, lease payments for land and property which are in state ownership, transfers by FGUPs of a portion of their profit left after payment of taxes and other mandatory payments (from 2001) and revenues from business activities of JV Vietsovpetro (excluding the 2008-2010 period and 2012 when there were no revenues).

*** with taking into account the funds received from the Central Bank of the Russian Federation from the sale of shares of OAO Sberbank of Russia (Rb 159.3bn), which factor, probably, overstates to some extent both the absolute value and the estimate of the aggregate unit weight of non-renewable sources as the above funds were not credited to the budget in full, but less their balance-sheet value and the amount of expenditures related to the sale of the above shares. Consequently, the share of renewable sources is understated to some extent.

Source: laws on execution of the federal budget in the 2000-2011 period; the report on execution of the federal budget as of January 1, 2013, www.roskazna.ru and the authors' calculations.

Implementation of proposals prepared in mid-March by the Ministry of Economic Development of the Russian Federation as regards the expansion of the privatization plan may yield up to $\mathrm{Rb}$ 1 trillion in case of secondary offering of packages of shares of five large companies (Aeroflot, Sheremetievo, Rostelekom, OZK and Rosneft). Last autumn, among the entities which were expected to be privatized in 2013 were packages of shares of eight companies (Rosneft, VTB, Sovkomflot, ALROSA (in February a selection of agents for sale of $7 \%$ of the equities of the company took place), Archangelsky Tralovy Flot (Archangelsk Trawler Fleet), TGK-5, Mosenergostroi and the Sibir Airline) which could be sold for Rb 260bn to Rb 270bn.

So far, the draft order - approved by the Government of the Russian Federation on April 11, 2013 - on amendment of the existing privatization program provides for inclusion in it of 54 jointstock companies, 14 FGUPs and 149 other state-owned entities. It is to be noted that no large assets were included in the above list of companies.

The general prospects of privatization have been determined the Federal Property Management State Program - approved by Resolution No.191-r of February 16, 2013 of the Government of the Russian Federation - which provides for carrying out on an annual basis of at least four deals on sale of large entities attractive for investment through public offering (from the number of entities envisaged for sale in the current year by resolutions of the President of the Russian Federation and/or the Government of the Russian Federation), while the total sum of funds to be received from privatization in the 2012-2016 period amounts to over Rb 3 trillion and exceeds the revenues from privatization in the past 18 years. 
It is difficult to speak about the actual achievements of the declared targets having in view the concrete value of federal budget revenues from privatization as it depends both on the list of assets which are expected to be sold and their cost related to evaluation procedures and the stock market situation which closely correlates with the macroeconomic situation.

The 2012 results explicitly pointed to the fact that the set of problems which is classical to the entire Russian privatization - justification of the fair price on assets to be privatized, real motivation of participants, determination of the criteria of selection of a buy, ensuring of transparency and claims of regulating authorities - is still topical. Also, there has been no analysis of the potential effects of the privatization with its expediency, alternative costs, possible risks and effects on individual markets, industries, regions and the country's economy as a whole taken into account. 